\title{
500 - lecie śmierci św. Antoniego Supraskiego
}

\author{
arcybiskup Jakub Kostiuczuk \\ Wydział Teologiczny, Chrześcijańska Akademia Teologiczna w Warszawie \\ Polska \\ bpjakub@orthodox.bialystok.pl
}

abp Jakub Kostiuczuk, 500 - anniversary of the death of St. Anthony of Suprasl, Elpis, 17 2015: 7.

Dzisiejszą konferencję rozpoczęliśmy Boską Świętą Liturgią. Teraz przechodzimy do części konferencyjnej. Liturgia w cerkwi miała szczególne znaczenie ponieważ tematem głównym dzisiejszej konferencji jest 500-lecie męczeńskiej śmierci św. Antoniego Supraskiego. W dniu dzisiejszym mija 500 lat od wydarzenia, które miało miejsce w obecnej Grecji, w Salonikach. Była to śmierć jednego $\mathrm{z}$ braci supraskiego monasteru. Św. Antonii dokonał swego końca życia w sposób męczeński. Jego droga do świętości była nietypowa. Kiedy opowiadamy o jego życiu, czasami wywołuje u słuchaczy zdziwienie, czasami kontrowersje. Droga św. Antoniego jako mnicha rozpoczyna się od tragicznego wydarzenia. Mianowicie w porywie emocji zabił człowieka. Zawsze ten epizod $\mathrm{z}$ jego życia budzi pewne zdziwienie, ale te wydarzenie wpłynęło na dalsze jego życie i męczeńską śmierć. Całe życie żył z świadomością jakiego grzechu dokonał. Ten grzech powodował ciągłą skruchę, ciągła pamięć o tym wydarzeniu. W zamyśle jego było oddanie swojego życia za wiarę w Chrystusa w męczeński sposób. W ten sposób w zamyśle tego człowieka było to ze chce odkupić swój grzech. Na pewno całe życie poświecił w modlitwie za tego którego zabił. To też ważny element jego życia i element pokuty ponieważ człowiek pokutujący za swój czyn bierze odpowiedzialność za życie tamtego człowieka, któremu przerwał bieg życia i w swojej modlitwie modlił się nie tylko za siebie, lecz również za człowieka którego zabił.

Dlaczego mówię o nietypowej świętości? Dlatego, że jeżeli zapoznamy się z twórczością Ojców Kościoła, nie znajdziemy nigdzie miejsca żeby zachęcali kogoś do sprowokowania śmierci, mimo śmierci za naukę Chrystusa. Nieprzypadkowo jeszcze ten młody człowiek, chce w pewien sposób odkupić swoje życie oddając życie za wiarę, to ci duchowni którzy kierują jego życiem - ihumen Pafnucy - przełożony monasteru w Supraślu oraz nieznani ojcowie na św. Górze Atos powstrzymują go od tego zamysłu. Nasze życie i pokuta nie polega tylko na tym, żeby szybko pójść i oddać swoje życie bo dokonaliśmy wielkiego grzechu. Bóg nie potrzebuje naszej śmierci. Właściwie wschodnie chrześcijaństwo podkreśla, że pojęcie relacji człowieka z Bogiem nie polega jurydycznej relacji. To że każdy grzech potrzebuje jakiegoś czynu odkupienia. Bóg oczekuje wewnętrznej przemiany człowieka, tej światowości grzeszności, swoje nicości przed Bogiem i oddaniu się modlitwy - oddania się Bogu. To powinno być celem życia każdego człowieka. I to czy ktoś dokonał wielkiego grzechu czy dokonuje grzechu codziennie, chociażby myślami. Każdy potrzebuje tej wewnętrznej przemiany, tej świadomości swojej nicości przed Bogiem. To tez nic dziwnego, ze ci duchowni którzy kierowali jego życiem powstrzymywali od jego zamysłu. Lecz po tym jak żył przez kilka lata na św. Górze Atos, z błogosławieństwa swego starca idzie do miasta Saloniki - do byłej chrześcijańskiej świątyni. W tej świątyni, w tym czasie modlili się muzułmanie. On zaczął modlić się po chrześcijańsku, co spowodowało że został wyprowadzony $\mathrm{z}$ budynku. Po tym jak nie chce się wyrzec nauki i wiary w Chrystusa - zabijają go. I stąd też droga jego do świętości jest nietypowa. Może nawet na pierwszy rzut oka, jeśli nie zastanowimy się nad jego celem drogi życiowej - nawet kontrowersyjna. Bóg prowadzi każdego do przemiany w różny sposób. Mamy nawet podobny żywot św. Mojżesza Murzyna, który tez zabił człowieka i diametralnie zmienił swoje życie. Te żywot św. Antoniego Supraskiego jest bardzo podobny do żywotu św. Mojżesza nazywanego Murzynem. Postać św. Antoniego była zapomniana. Kiedy w 80 latach XX wieku wznowione życie monastyczne nie mieliśmy informacji w kalendarzu. Nie świętowaliśmy 17 lutego dzień jego pamięci. Po prostu nie wiedzieliśmy nic o nim. Dopiero na początku XXI wieku zaczynają się pojawiać informacje o świętym i ostatecznie dużo materiałów zostało zgromadzonych dotyczących jego życia i śmierci.

Pragnę serdecznie podziękować prof. Antoniemu Mironowiczowi, który dość dużo musiał się potrudzić aby te informacje odnaleźć. Została wydana książeczka z krótkim żywotem św. Antoniego autem którego jest pan profesor wraz z synem Marcinem.

Dziękuje również organizatorom dzisiejszej konferencji. Katedrze Teologii Prawosławnej Uniwersytetu w Białymstoku oraz Monasterowi Supraskiemu. Dziękuje wszystkim prelegentom, którzy zachcieli przybyć do nas i wygłosić swoje referaty. Zostaje mi życzyć owocnych obrad. 
ISSN 1508-7719

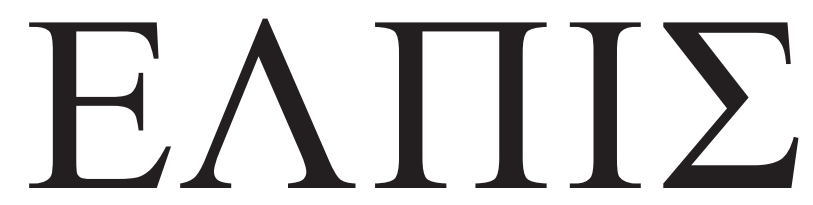

CZASOPISMO TEOLOGICZNE KATEDRY TEOLOGII PRAWOSŁAWNEJ UNIWERSYTETU W BIAŁYMSTOKU

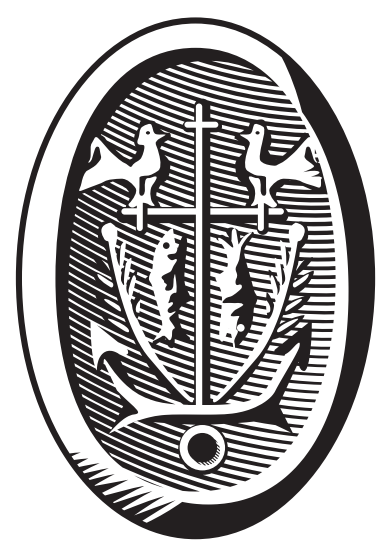

ADRES REDAKCJI

15-097 Białystok, ul. M. Skłodowskiej-Curie 14 tel. 85 745-77-80, e-mail: redakcja@elpis.edu.pl www.elpis.uwb.edu.pl 